Walisongo Law Review (Walrev), Vol 1 No. 2 (2019)

DOI: 10.21580/Walrev/2019.1.2.4817

Copyright (C) 2019 Walisongo Law Review (Walrev)

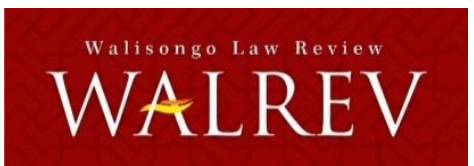

\title{
Legal Domicile of the Parties in a Simple Lawsuit
}

\author{
Artha Ully \\ Afiliasi: Pengadilan Negeri Cibinong, Bogor \\ e-mail: arthaully@gmail.com
}

\begin{abstract}
The purpose of this paper is to examine the publication of Perma No. 2 of 2015 concerning Procedures for Settling a Simple Lawsuit. Perma can be seen as one solution to meet the needs of the community for dispute resolution procedures quickly and simply. The substance contained in Perma is to uphold the principle of justice which is simple, fast, and low cost. Therefore, the requirements in a simple lawsuit are limited in nature, where if one of the conditions is not fulfilled, the case cannot be resolved through the Simple Lawsuit Procedure in accordance with Perma No. 2 of 2015. The results of the author's research, the Perma substance is needed to be improved, because the limitation of jurisdiction is only one legal domicile and the use of legal counsel in a simple claim is something that needs to be regulated in more detail, in the future to further encourage the use of a simple claim mechanism as a instrument of applying the principle of justice that is simple, fast, and low cost in Indonesia. The Supreme Court needs to regulate in more detail the role of the attorney in simple lawsuits, such as regulating the right to speak a legal representative and the problem of the absence of the principal in the event that the party is a legal entity; Electronic calling via Sms, whasapp and email can be an alternative used in the calling process, so Perma should regulate in more detail the
\end{abstract}


terms and conditions of the validity of the information technologybased calling.

Tujuan penulisan ini adalah untuk menelaah penerbitan Perma No. 2 Tahun 2015 tentang Tata Cara Penyelesaian Gugatan Sederhana. Perma itu dapat dipandang sebagai salah satu solusi untuk memenuhi kebutuhan masyarakat terhadap prosedur penyelesaian sengketa dengan cepat dan sederhana. Substansi yang terkandung di dalam Perma yaitu menjunjung asas peradilan yang sederhana, cepat, dan berbiaya ringan. Oleh karena ini persyaratan dalam gugatan sederhana bersifat limitatif, di mana bila salah satu syarat tidak dipenuhi, maka perkara tersebut tidak dapat diselesaikan melalui Prosedur Gugatan Sederhana sesuai PERMA No. 2 Tahun 2015. Hasil penelitian penulis, substansi Perma diperlukan pernyempurnaan, karena pembatasan yurisdiksi hanya pada satu domisili hukum dan penggunaan kuasa hukum dalam gugatan sederhana merupakan hal yang perlu diatur secara lebih rinci, di masa yang akan datang untuk lebih mendorong penggunaan mekanisme gugatan sederhana sebagai instrumen penerapan asas peradilan yang sederhana, cepat, dan berbiaya ringan di Indonesia. Mahkamah Agung perlu mengatur lebih rinci peran kuasa hukum dalam gugatan sederhana, seperti mengatur hak bicara kuasa hukum dan masalah ketidakhadiran prinsipal dalam hal pihak adalah badan hukum; Pemanggilan secara elektronik melahi SMS, WA dan email dapat menjadi alternatif yang digunakan dalam proses pemanggilan, maka PERMA sebaiknya mengatur secara lebih rinci syarat dan ketentuan keabsahan pemanggilan berbasis teknologi informasitersebut.

Keywords: simple lawsuit; quick justice; supreme court

\section{Introduction}

Improving access to justice is one of the main agendas of justice reform in Indonesia today to ensure access to justice for the general public, so the court process must be carried out effectively, quickly and affordably (Mahkamah Agung, 2010: 76). In practice the prerequisites are difficult to 
implement, this is related to the procedure for solving civil cases related to how the public can get guarantees to resolve their dispute, without a long and expensive judicial process.

In practice civil litigation is often protracted, postponed, or even unfinished because the deposit is used up. Even though the speed of the trial will increase the authority of the court and increase public confidence in the world of justice (Agustine: 2017: 5). The speed of the trial process also serves as a benchmark for legal certainty and a sense of justice in addition to the substance of the verdict that is acceptable to the parties.

One of the efforts and efforts taken by the Supreme Court of the Republic of Indonesia is to issue a Supreme Court Regulation No. 2 of 2015 concerning Procedures for Settling a Simple Lawsuit, hereinafter abbreviated to PERMA Number 2 of 2015 on August 7, 2015. This Perma is an instrument to provide a simpler and faster procedure for the settlement of a lawsuit, although it is still limited to claims that belong to the simple category, namely a lawsuit with a maximum material value of $\mathrm{Rp}$. 200,000,000 (two hundred million rupiah) and the proof is simple. The application of the principle of simplicity and speed can be seen from the time limit for claim settlement, which is 25 (twenty five) days from the day of the first hearing (Varia Peradilan, 2012: 61).

Another requirement in a simple lawsuit procedure is that the parties must be in one jurisdiction, but Perma No. 2 of 2015 does not provide a more detailed explanation of the legal domicile of the parties. Issues of domicile and power of attorney by the parties have the opportunity to abort the dispute resolution effort using a simple lawsuit, because in practice there is a possibility the parties or their proxies are not in the same jurisdiction. Based on the description above, the writer in this paper will examine the legal domicile of the parties in the Simple Lawsuit based on Perma No. 2 of 2015.

This artikel have problem, first, how to regulate legal domicile as a requirement Filing a simple claim based on Perma No. 2 of 2015? Second, how is the alternative solution to the problem of legal domicile requirements in a simple lawsuit procedure? 


\section{Arrangement of Legal Domicile by Perma No. 2 of 2015}

The presence of Perma No. 2 of 2015 is the implementation of the principle of simple justice, fast and low cost for justice seekers with a simple proof system. This Perma regulates, which in essence is as follows:

a. Plaintiff is an individual or legal entity;

b. There is a legal relationship which is the basis of the dispute with the Defendant;

c. The Defendant is in the same domicile / jurisdiction as you

d. The dispute is not related to land rights or other cases that are specifically regulated in legislation, such as consumer business competition.;

e. The value of the claim you file for the loss is at most Rp. 200,000,000.00.

Based on Perma Number 2 of 2015 the parties in a simple lawsuit must meet the following criteria:

a. Each plaintiff and defendant who is an individual or legal entity, the plaintiff or the defendant can be more than one if they have the same legal interests;

b. Plaintiff and defendant are in the same legal area, Article 4 paragraph (3) Perma Number 2 of 2015 expressly states that the Plaintiff and Defendant in a simple lawsuit are domiciled in the same court jurisdiction, meaning that if there is an inequality of legal domicile, the parties do not can use a simple suit container;

c. For a defendant whose place of residence is unknown, a simple lawsuit cannot be filed;

Article 4 paragraph (2) of PERMA Number 2 of 2015 states that for a defendant whose residence is unknown his simple claim cannot be filed. Based on this article, it is known that the summons of the parties determined that the defendant's residence address should be known, so that the defendant whose place of residence is unknown could not be summoned. 
d. Plaintiffs and defendants are required to attend directly each trial with or without their legal counsel.

The use of legal counsel in a simple lawsuit is regulated in Article 4 paragraph (4) Perma 2 of 2015 which states that the Plaintiff and Defendant are obliged to directly attend each trial with or without a legal counsel, meaning that the Plaintiff and Defendant are obliged to be present principally even though they have been accompanied by an attorney law.

Article 4 paragraph (3) Perma No. 2 of 2015 states that the Plaintiff and defendant in a simple lawsuit domiciled in the jurisdiction of the same Court," the word domicile must be translated decisively because according to the provisions of Article 118 (1) HIR states the term residence and residence, so it is necessary to ascertain what is meant by domicile in the Perma refers to the residence or residence.

According to the large Indonesian dictionary the domicile is a permanent and official residence of a person, where he is registered as a resident (KBBI, 2009: 197). Article 4 paragraph (3) does not follow the use of the term as a place of summons as mentioned in Article 118 HIR, HIR itself does not stipulate in more detail about the domicile both the residence and residence. In practice, the residence where someone is de facto (fact or reality) is located, while the residence is the place where someone de jure (legally) lives or is legally domiciled as a resident.

Provisions that a simple lawsuit can only be filed if the Plaintiff and Defendant have the same domicile will be very limiting, because the legal or contractual relationship does not look at the territorial boundaries and can even cross national borders. $n$ every legal dispute it will always be related to domicile, because it will determine the court where the dispute will be filed. Perma chose to use the term domicile which refers more to the legal residence, whereas Article 118 HIR adopted the principle of actor secuitor forum rei where the lawsuit was filed at the Defendant's residence and if the residence was unknown, the lawsuit was filed at the Defendant's residence. 
Simple lawsuit settlement can only be done to parties who live in one domicile, this can be interpreted as a simple lawsuit having the provision that the plaintiff and the defendant in dispute must be domiciled in the same Court jurisdiction. Actually this aims to facilitate the settlement of the case. This provision is also a limitative requirement for a simple claim, the domicile of the plaintiff and the defendant in the jurisdiction of the same Court is required in a simple lawsuit with the aim of suppressing the estimated cost of summons and notifications. The domicile of the law itself can be interpreted that the place of residence or residence chosen by the parties when registering the lawsuit, the domicile of the law relates to the place where the court will be willingly submitted (domicile relaas).

In determining the advance of court fees, the cost of summons and notification is the most important estimate calculated, in relation to the amount of the bailiff's transportation to the plaintiff's place and the defendant's. The farther away these parties live, the greater the costs of calls and notifications being set. In addition, this provision also shortens the time of calling the litigants. If the litigants are domiciled in the jurisdiction of the same Court, then the bailiff in the District Court where the parties are domiciled will be easier and faster in delivering the summons (relaas), so that the hearing can be held according to the schedule determined by the judge. The provisions of the plaintiff and the defendant in dispute must be domiciled in the same jurisdiction as well as increasing the chances of the plaintiff and the defendant in dispute attending the trial directly.

\section{Alternative Remedies for Legal Domicile Requirements}

In practice, one alternative that can be used in resolving the problem of legal domicile of the parties in a simple claim is the use of legal counsel, the plaintiff may use the services of a legal representative domiciled with the Defendant and use the address of the attorney as the domicile of the plaintiff. The Simple Lawsuit Perma does not prohibit the use of lawyers' services or attorneys, because in Article 4 Paragraph (4) Perma No. 2 of 2015 there is the phrase "with or without a legal representative".

The parties are allowed to use legal counsel, because the principal is still required to be present even if accompanied by a legal representative at the 
hearing. The next question is whether the principal plaintiff's presence is mandatory or can be set aside if the party in the simple lawsuit is a Legal Entity. The principal party in a legal entity is the legal entity institution legal entity itself, for example in a Limited Liability Company the Principal is a Limited Liability Company, but a Limited Liability Company provides its power of directors through its Articles of Association that those who represent the legal interests of a Limited Liability Company are directors. The presence of both plaintiffs and defendants who have legal representation should be attended by plaintiffs and principal defendants, so that the simple litigation process can be completed more quickly and the judge can actively seek peace because the judge deals directly with the parties concerned, provisions must be present for the plaintiff or the defendant needs to be arranged in more detail in the event that the party in the simple lawsuit is a Legal Entity.

When you see again that a simple lawsuit is an instrument of the embodiment of the principle of quick, simple and low-cost proceedings, the court, especially the judges, according to the author, is wiser to judge whether the presence of a principal is necessary or not. If one of the parties wishes to be represented by a legal representative for reasons that are understandable and acceptable as in if the party is a legal entity, then the absence of the principal is directly acceptable to the judge.

The next question is whether a legal representative in a simple lawsuit also has the right to speak during the examination process or only the principal has that right. Perma No. 2 of 2015 does not stipulate in more detail about this issue, it can be interpreted that the attorney has the right to speak which in the process must be with the judge's permission because the judge presides over the proceedings. The right of speech is actually given to the principal, so that the legal counsel in submitting the proposition and opinion must be approved by the principal, if the principal who is accompanying him is present at the hearing.

The second alternative, that can be used in solving the problem of legal domicile of the parties is the Simple Suit Act adopts the development of information technology that can be used in facilitating the summons of the parties. Simple lawsuit procedure can implement an electronic calling 
system using electronic communication tools such as SMS, WA or special email for the Plaintiff, because the Plaintiff is present when registering a simple claim, whereas for Defendants continue to use calls through the confiscator (relaas).

At the time of registering a claim, the Plaintiff includes an active and contactable telephone, mobile, WA and e-mail number, so that notice is sufficient to be made via SMS, WA and e-mail that can be directly received by the Plaintiff and the delivery notification can be recorded. The problem of the plaintiff and the defendant who is not a legal domicile, the lawsuit can still be filed in the jurisdiction where the Defendant is domiciled and the Plaintiff is sufficiently summoned via SMS, WA or email and even though the different parties domicile the summons can still be delivered on time.

Civil procedural law should begin to adopt the dynamics of information technology, because the conventional calling model regulated in the HIR and RBG through the Village Head is felt to be ineffective. This happens because often the Village Head does not forward or deliver the summons (relaas) to the interested parties. The use of information technology-based communication tools such as telephone, SMS, WA and email can be an alternative used in the calling process, then the procedural law will determine the terms and conditions of the validity of the call (Mansyur and Witanto, 2017: 93).

The District Court as part of the General Court has the duty and authority to settle disputes or disputes that are civil in nature based on Civil Procedure Law by maintaining, implementing and enforcing material civil law through the judicial process. Thus, the role of the court can be placed as an instrument of behavior owned by the General Court which functions as an important means of resolving disputes or disputes in the community, providing legal protection, legal order, public safety, even its usefulness must be based on law and justice.

Perma and Sema act as fillers of the legal vacuum, complement legal shortcomings, facilities for law enforcement, facilities for legal discovery, and as a source of Indonesian law towards the realization of great justice. The role of Perma and Sema can be placed as a set of behaviors owned by the Supreme Court which functions as a legal guideline in regulating 
regulations, filling legal vacuum, and creating law in the context of Indonesian legal development (Topa, 2017: 52-53).

The role of Perma as a fill in the legal vacuum is also mentioned in Perma's consideration No. 2 of 2015 concerning Procedures for Settling a Simple Lawsuit. The urgency of this Perma is also motivated by the need for simpler, faster and less costly dispute resolution procedures, especially in legal relations that are simple in the development of legal relations in the economic and other civil fields in society.

Perma No. 2 of 2015 does not regulate in more detail the issue of legal representation in a simple lawsuit, according to the authors the Supreme Court needs to regulate in more detail the role of legal counsel in a simple lawsuit such as regulating the power of speech of lawyers and the issue of the absence of principals in terms of certain reasons that can be accepted according to the development of practice trials that have developed so far.

Simple Lawsuit Procedure which is a form of implementing dispute resolution quickly, simple and low cost can begin to implement the functions and uses of information technology, because the conventional calling model regulated in the HIR and RBG through the Village Head is felt to be ineffective. This happens because often the Village Head does not forward or deliver the summons (relaas) to the interested parties.

The use of information technology-based communication tools such as telephone, sms, whatsapp and email can be an alternative used in the calling process, then the procedural law governed by Perma which acts as a fill in the legal vacuum, complements legal deficiencies, means of law enforcement, means of legal discovery and as a source of law will determine in more detail the terms and conditions of the validity of the summons based on the use of the information technology.

\section{Simple Lawsuit Arrangement in Perma 4 of 2019}

In the preamble Perma Number 4 of 2019 stated that:

a. The implementation of Perma Number 2 Year 2015 concerning Procedures for Settling a Simple Lawsuit received a positive 
response from the community in resolving disputes and seeking justice;

b. To optimize the settlement of a simple lawsuit by perfecting Perma Number 2 of 2015, especially in this case the value of the material lawsuit, the jurisdiction of the plaintiff and the defendant, the use of electronic case administration, verification, confiscation and execution procedures;

The change material contained in Perma No. 4 of 2019 include the following:

Table 01 - change material contained

\begin{tabular}{|c|c|c|}
\hline No. & Material of Chang & Perma No. 4 of 2019 \\
\hline 1 & Lawsuit value & $\begin{array}{l}\text { The maximum value of the material } \\
\text { claim is Rp. 500,000,000.00 }\end{array}$ \\
\hline 2 & Litigation & $\begin{array}{l}\text { a. It is permissible for the plaintiff } \\
\text { and the defendant not to be in } \\
\text { the jurisdiction of the same court } \\
\text { as long as the plaintiff appoints } \\
\text { an incidental power of attorney, } \\
\text { that is, power of attorney } \\
\text { domiciled in the domicile of the } \\
\text { defendant. } \\
\text { b. Plaintiffs and defendants must } \\
\text { attend court and may be } \\
\text { accompanied by a legal or } \\
\text { incidental attorney. }\end{array}$ \\
\hline 3 & Filing a lawsuit & $\begin{array}{r}\text { The plaintiff can register the claim } \\
\text { electronically according to statutory } \\
\text { regulations }\end{array}$ \\
\hline 4 & Calling the parties & $\begin{array}{l}\text { a. If the defendant is absent from } \\
\text { the first and second hearings, } \\
\text { then the judge can decide } \\
\text { verstekly (decide without the } \\
\text { presence of the defendant). }\end{array}$ \\
\hline
\end{tabular}




\begin{tabular}{|c|c|c|}
\hline & & $\begin{array}{l}\text { Defendants can file verzet } \\
\text { (Resistance). With respect to the } \\
\text { verdict after verzet, the } \\
\text { defendant may submit an } \\
\text { objection. } \\
\text { b. If the defendant is present at the } \\
\text { first hearing and does not attend } \\
\text { the second hearing, the decision } \\
\text { is contradictory. This decision } \\
\text { could be objected by the } \\
\text { defendant. }\end{array}$ \\
\hline 5 & Inspection process & Confiscation can be done \\
\hline 6 & Proof & $\begin{array}{l}\text { A claim that is recognized } \\
\text { unanimously does not require } \\
\text { additional substantiation. }\end{array}$ \\
\hline 7 & $\begin{array}{l}\text { Implementation of } \\
\text { the decision }\end{array}$ & $\begin{array}{l}\text { It is further regulated regarding } \\
\text { Aanmaning (summoning of the party } \\
\text { to execute the decision voluntarily). } \\
\text { The rules are: } \\
\text { a. The Chief Justice of the court } \\
\text { appointed Aanmaning seven } \\
\text { days after the request for } \\
\text { execution. } \\
\text { b. The Chairman of the Court sets } \\
\text { the date for the implementation } \\
\text { of the aanmaning seven days } \\
\text { after the aanmaning is } \\
\text { determined. } \\
\text { c. If the geographical condition is } \\
\text { not possible to carry out } \\
\text { aanmaning within seven days, } \\
\text { then the execution time allowed } \\
\text { is not in accordance with the } \\
\text { provisions. }\end{array}$ \\
\hline
\end{tabular}

Please note that material other than and the rest as above material in Perma No. 4 of 2019 is still the same as Perma No. 2 of 2015, there are at least 2 (two) problems that have not been accommodated by Perma Number 4 of 2019, including: 
a. The mechanism for laying of confiscated collateral is not regulated; and,

b. Not governed verzet examination period.

Nevertheless, the issuance of Perma Number 4 of 2019 is expected to be able to reduce the time for hearings in court, where the estimated total total time for simple dispute settlement stages only takes 79 (seventy nine) days. In addition, the new regulation on this simple lawsuit is an integrated solution, reflects the principles of building blocks, as a transition to modern justice based on information technology, and supports transparency \& accountability, as well as access for registered users (advocates).

\section{Conclusion}

Attempts by the Supreme Court to issue Perma No. 2 of 2015 concerning Procedures for the Settlement of Simple Lawsuit is one solution to meet the needs of the community for faster and simpler dispute resolution procedures, the substance contained in the Perma is nothing but to uphold the principle of justice which is simple, fast, and low cost. The requirements in a simple Lawsuit are limited in that if one of the conditions is not fulfilled, the case cannot be resolved through the Simple Lawsuit Procedure in accordance with Perma No. 2 of 2015.

The substance of Perma No. 2 of 2015 needs to be improved because the limitation of jurisdiction to only one legal domicile and the use of legal counsel in a simple lawsuit is something that needs to be regulated in more detail in the future to further encourage the use of a simple claim mechanism as an instrument to apply the principle of simple, quick justice, and low cost in Indonesia.

The Supreme Court needs to regulate in more detail the role of the attorney in simple lawsuits, such as regulating the power of speech of attorneys and the issue of principal absence in the event that the party is a legal entity; Electronic calling via sms, whatsapp and email can be an alternative used in the calling process, so Perma should arrange in more 
detail the terms and conditions of the validity of the information technologybased calling. [w]

\section{Noted:}

Article 118 paragraph (1) HIR: A civil suit or claim for rights which at the first level enters the authority of a district court, must be submitted with a request letter signed by the plaintiff or his representative according to Article 123 to the chairman of the district court in the jurisdiction of whom the defendant is residing or if unknown where he lived, to the actual residence.

\section{Reference}

Agustine, Dwi. 2017. "Pembaharuan Sistem Hukum Acara Perdata”, Jurnal Rechts Vinding 2 (6): 1-7.

Topa, Jeims Ronald. 2017. "Peranan Pengadilan Dalam Penyelesaian Gugatan Sederhana Di Pengadilan Negeri”, Lex Adsministratum, 4 (5).

Departemen Pendidikan RI. 2009. Kamus Besar Bahasa Indonesia Jakarta: PT. Media Pustaka Phoenix.

Mahkamah Agung. 2010. Cetak Biru Pembaruan Peradilan 2010-2035, Jakarta: Mahkamah Agung.

Mansyur, Ridwan and Witanto, D.Y. 2017. Gugatan Sederhana: Teori, Praktik dan Permasalahannya. Jakarta: Pustaka Dunia.

Majalah Varia Peradilan, edisi 321, Agustus 2012. 